\title{
A PHENOMENOLOGICAL STUDY OF INSTAGRAM FASTING ON MILLENNIAL
}

\author{
Eny Ratnasari \\ Padjadjaran University, Indonesia \\ eny12001@mail.unpad.ac.id \\ Fikri Dwi Oktaviani \\ Padjadjaran University, Indonesia \\ fikri13001@mail.unpad.ac.id
}

\begin{abstract}
The aims of this study is to find out: (1) the background of doing Instagram fasting; (2) things that were felt before doing Instagram fasting. The main reason for this millennial generation to do Instagram fasting is the discomfort of the experience of using Instagram. The informants agreed that Instagram is currently becoming poisonous or toxic which has a negative impact on their psychological. They seemed to be chased by something that was so obsessed that they were afraid to miss something or Fear of Missing Out (FOMO). After fasting, the informants claimed productivity increased, distraction decreased, more positive thinking.
\end{abstract}

Keywords: $\quad$ Fear of Missing Out, Millennial Generation, Social Media, Instagram Fasting

\begin{abstract}
Abstrak
Tujuan dari penelitian ini adalah untuk mengetahui: (1) latar belakang melakukan puasa Instagram; (2) hal yang dirasakan sebelum melakukan puasa Instagram. Hasil penelitian menunjukkan bahwa puasa Instagram dilakukan sebagai upaya untuk mengurangi intensitas penggunaan media sosial Instagram. Alasan utama generasi milenial ini melakukan puasa Instagram adalah adanya ketidaknyamanan akan pengalaman penggunaan Instagram. Para informan sepakat bahwa Instagram saat ini menjadi racun atau toxic yang berdampak buruk pada psikologis mereka. Mereka seakan dikejar sesuatu yang membuat terobsesi sehingga takut untuk ketinggalan sesuatu atau Fear of Missing Out (FOMO). Setelah melakukan puasa, para informan mengaku produktivitas meningkat, distraksi menurun, lebih berpikir positif.
\end{abstract}

Kata Kunci: Fear of missing out, generasi milenial, media sosial, puasa Instagram 


\section{Introduction}

Instagram is closely related to millennial life. In Indonesia, the use of social media Instagram were increasing every year. Based on the research which conducted by Hootsuite and We are social, there are 53 million Instagram active users every month or 20 percent of the total population of Indonesia (men 51\% and women 49\%). The most dominant users were among 18 - 34 years which has characteristics young, educated, and financially stable. The average daily social media usage is 3 hours.

APJII has surveyed internet usage in Indonesia. It shows that 143 million Indonesians use internet. Specifically, 91\% consisted of Generation Y or millennial (born in the 1980s and 2000s) and 89\% consisted of Generation Z (the generation currently in high school and junior high school). APJII's findings state that these two generations in their daily lives access the most social media. This fits the millennials characteristics who good at technology.

Instagram is a social media that allows users to show who they are through photos, videos, captions, and so on. Instagram users can freely express themselves to show themselves. In other words, a person's selfimage can be reflected through his social media accounts. At a certain intensity, Instagram does bring entertainment and even kindness.

Among these users, there were users which often checking their Instagram accounts. Either just see how many people give likes to their uploads or to follow other people's lives through Instagram Story. Unconsciously, Instagram users not only show their best side in cyberspace. In accordance with the statement of social media expert Bailey Parnell in a TEDxRyersonU forum, "The first stressor on social media is highlighting the best collection and the brightest moment."

When a person arranges the front page on social media, then he seems to choose the best outfit or what color suits themselves. Likewise, when a user wants to upload a new photo accompanied by caption, also 
the user experiences a process as if he wants to express something to the other person who is in front of him. For users who realize that other users are not just one, structuring social media will be an act that is not necessarily spontaneous. But through a long process that occurs within itself.

The current phenomenon is addiction to virtual responses and technological addiction. As reviewed by tirto.id, the first concept to be reviewed is about the "tech zombie epidemic" or the technology addiction phenomenon that is illustrated by the sensation of getting likes and the desire to continue to know whether someone who is the interlocutor in cyberspace chat has read or reply. Therefore, people will constantly be faced with their cellphone screen.

Concerning about the effects of addiction, technology companies basically implement several persuasive and motivational techniques with the aim of binding users to continue using their products. In an article titled This Is How Technology Turns Us Into Addicts published in the World Economic Forum, revealed several techniques commonly embedded in digital technology. These techniques include scarcity, social proof, personalization, and reciprocity. These four techniques are very obvious used on Instagram (Wahyuni, 2018).

Scarcity is implemented by making technology or features available as if they were scarce or available in a period of time so as to encourage users to go online and check them out. This applies to Instagram Story which just available for 24 hours or upload. Social Proof is implemented through validation of likes on an upload in order to influence users to immediately check it. Personalization is implemented by designed to filter and display feeds, so that users try to represent themselves based on their likes and interests. Reciprocity is an interaction scheme of friendship circle competition in the media which makes it hard for users to leave social media. 
There is a saying that all that is excessive is not good. No exception with the use of Instagram. Excessive use of fact has a negative impact on one's mental health. Various studies on social media and the negative effects it has caused have been carried out. The results shows that social media has an effect on decreasing sleep quality, bullying, and the appearance of Fear of Missing Out (FOMO) symptoms. Not even a few who feel depressed or anxious (McCloskey et al., 2015).

Features on social media lead to the concept of Fear of Missing Out (FOMO). This concept is based on the substance of technology that is designed on the basis of basic human needs to create a sense of ownership and attachment to others. The existence of the last feature seen in the application (last seen), the marker has seen a message (read mark with eye images) on the Instagram application, it makes users aggressive in viewing messages and raising the desire to respond quickly. Instagram also doesn't have the bottom edge. Ry (2018) said that "therefore, users become obsessed or don't want to stop scrolling pages". The tendency of addiction to Instagram is coupled with the pampering of users with the pull to refresh and story features.

In this study, active users of Instagram admit that they are already uncomfortable with Instagram. They also felt something was wrong with them when accessing Instagram. Finally, they decided for doing Instagram Fasting. Instagram fasting in Indonesia has only just begun in 2018. After earlier in 2017, many people started fasting on social media. Specifically, fasting was doing on Instagram since the start of the Instagram story feature, FC (2018) said that "Instagram users feel that many users have a tendency to show off".

Based on the phenomena that occur, problem that need to be answered on this paper is how was the experience of Instagram users from millennial generation while doing Instagram fasting? The aims of this study are to find out: (1) the background of doing Instagram fasting; 
(2) things that were felt before Instagram fasting; (3) things that were felt while doing Instagram fasting; (4) things that were felt after doing Instagram fasting. This study is considered necessary because millennial generation and social media are closely related. Millennial generation is currently on its productive age and the largest internet user in Indonesia.

\section{Research Questions}

From the background of the problem above, the focus of the problem is want to reveal how the experience of millennial generation of Instagram users in doing Instagram fasting. The purpose of this study is to find out: (1) the background of fasting Instagram; (2) things that were felt before Instagram fasting; (3) things felt when doing Instagram fasting; and (4) things felt after fasting on Instagram

\section{Research Method}

This study wants to reveal the experience which felt by millennial generation of Instagram users who doing Instagram fasting. Phenomenology studies are considered appropriate to examine this phenomenon because phenomenology seeks to describe the meaning of the life experiences of several individuals regarding the concept of the phenomenon they are experiencing. Phenomenologists try to study the structure of consciousness in individual experiences. One aspect of phenomenology that is widely discussed in social sciences in particular relating to research methodology is an understanding from within or a behavioral perspective.

Edmund Gustav Albrecht Husserl formulated phenomenology as a science of the essence of consciousness. Husserl revealed that to get meaning, researchers need to transform the structure from implicit experience to explicit. The central concept of Husserl's thinking is about intentionality in the sense that human consciousness never stands alone. 
Phenomenology Husserl wants to analyze the world of human life as he experiences it subjectively, inter-subjectively, and objectively. Subjective is the personal experience of humans as when living life. The objective is the world around humans which is permanent in time and space. Intersubjectivity is the worldview of all people involved in social activities in the living world. Smith et al., (2009) writes, "it is this interaction between the subjective, objective and inter-subjective worlds that is the study of phenomenology" (Zahavi, 2003).

In this study, researchers are possible to conduct data analysis with Interpretative Phenomenology Analysis (IPA). In the use of natural science research follows the flow of analysis, namely (1) Reading and rereading; (2) Initial noting; (3) Developing Emergent Themes; (4) Searching for connections across emergent themes; (4) Searching for connections across emergent themes; (5) Moving the next cases; (6) Looking for patterns across cases.

This study was conducted by observation and in-depth interviews with 20 Instagram users who fasted Instagram. The informants consisted of 5 men and 15 women. They are active Instagram users since 2014 with age range 20-26 years old. Before doing Instagram fasting, in their daily life they access Instagram more than 3 hours. The informants of this research also have been doing Instagram fasting for at least 1 month. We maintain the privacy of the informants by using initials.

\section{Results and Discussion}

When social media users are rapidly increasing all over the world. Instagram fasting has become a popular phrase in the past 3 years. Producers of social media also rack their brains to implement accurate strategies that are deliberately made, so that social media users feel comfortable and even continue to use Instagram. 
Etymologically, fast means that restraint. Conceptually, fasting is often identified with Muslims. In Islamic teachings, fasting comes from the word shaum which literally means to refrain from everything (Musfah, 2004).

Instagram is a social media that facilitates users to share photos and videos, apply digital filters, and share them with various social networking services. The development of Instagram is very rapid. The utilization is like as 2 blades, can be positive or negative. It depends on who use it.

Instagram fasting is interpreted differently by informants who are millennial generation. The informants interpreted Instagram fasting as an effort to reduce the intensity of the use of Instagram. The meaning of Instagram fasting which is summarized from the opinions of the informants are as follows: (1) Remove the applications from mobile phones; (2) Deactivating Instagram accounts; (3) Limit theirself or reduce the frequency to access Instagram once a week, once every two weeks, or even once a month even if they don't delete the application on their mobile or through the computer; (4) Didn't access the Instagram website on computer; (5) Turn off Instagram notifications totally; (6) Tell colleagues that they are not using Instagram.

The infomans revealed their experiences while doing Instagram fasting. RY informants interpret Instagram fasting by deactivating Instagram accounts. RY fasted for one month. DF informants have been fasting Instagram more than 3 months. During this time, she didn't delete the Instagram application from her cellphone except he never used Instagram. And, Df (2018) said that "until now she still rarely uses Instagram".

NR is an informant (2018) has done Instagram fasting initially for about a month. After that, 6 months later he accessed Instagram but he never opened uploads and Instagram stories of his friends. So, after fasting the NR informant uses Instagram only for fangirling. 
JNG is an informant (2018) who has done Instagram fasting to delete her Instagram account for more than one month because she wants to focus on completing his college assignments.

Yeah, so at that time I never opened Ig until I deactivated my account, deactive account, a month if I'm not mistaken. The reason was that at that time I wanted to focus on working on my lapjob because I thought I was disturbing that I was working on my report. It's like a little open Ig even though only liatin instastories of people. Finally I really deactivated-in account and uninstalled the Ig application from my cellphone (Jng, 2018)."

Unlike the case with OTN and FO are an informant (2018), Instagram fasting which is interpreted by OTN and FO informants is an activity when they reduces the frequency of using Instagram to once a week or even not opening Instagram at all. Although the Instagram application is still in the device.

"Once in a phase because Instagram was boring, then it was just because I was busy so I didn't even think about opening it. The one who does not open Ig weekly because of being bored with Ig content at that time, also saturated open Ig. Even now I open the Ig a day not until an hour. Now I prefer to open Twitter or Youtube (Otn, 2018)."

"Once, I often opened Ig so often, so I rarely. The problem is that dependency is like that, before every minute I opened Ig and kept thinking about reducing the beginning of a day two days without gabuka, continued three days, continued a week until now, thank God, I became dependent (Fo, 2018)."

TL is an informant (2018) that has done Instagram fasting by removing the Instagram application in her device. She revealed that she only opens her Instagram account when she is finishing work on her laptop.

CI is an informant (2018) that has done fasted Instagram about two or three months ago. She has done Instagram fasting due to feeling bored 
and bored with life in cyberspace. Instagram fasting is done by removing the Instagram application in the device but not to delete her Instagram account.

Almost similar to other informants, $\mathrm{Fz}$ is an informant (2018) that has done claimed to Instagram fasting almost 3 months longer. Instagram fasting is done by deleting all collections of photos and videos in her Instagram account, and don't uses Instagram either to just search for information, establish communication, or even just to provide entertainment.

\section{Reasons of Doing Instagram Fasting}

Millennials of Instagram users have different reasons in doing Instagram fasting. From the informants's experienced, we found a similarity. We named it the inconvenience of the experience of using Instagram. Briefly, Instagram is just like poison in the lives of informants. The informants are aware that Instagram is not healthy, especially for their mental health. They find solutions by exchange ideas with friends or finding their own ways.

The informants felt that he always wanted to open Instagram at every opportunity, as if Instagram seem to be addictive for them. They are afraid to miss something new or better known as FOMO (Fear of Missing Out). The informants also felt that something was wrong with them. Physically they do not experience problems, but psychologically they feel jealous, compare their own lives with others, and nervous. In the end, the things that felt by the informants make them unproductive because their time is up for scrolling Instagram.

The features provided by Instagram currently facilitate some people who want to exist in cyberspace by showing the best side of their lives. This is what makes the informants choose to do Instagram fasting. Displaying the best side of their life through Instagram Story features 
makes informants uncomfortable from the psychological side. The informants felt that nowadays people tend to use Instagram Story to show off "their perfect life" or the best side of life, such as luxury, consumptive life, and achievement of something that makes the informants jealous because they compare their lives with others.

The number of ads that enter so that inevitably have to be watched is another reason that lies behind the decision of the informants to do Instagram fasting. Instagram algorithm that shuffles someone's uploads so that it confuses users about old uploads and new uploads as well as become complaints from informants. This was revealed by a KZF informant who thinks that she does not feel the benefits of Instagram for herself. Too many new features such as IG TV and shop which she found odd. Then more and more people are selling (online shop) which makes them uncomfortable. Instagram uploads that are not time-based make users confused. Plus, what makes users bored is what is displayed is the upload of certain people and tends to be monotonous (that's all).

US is an informant (2018) that has done Instagram fasting for several reasons including the following : (1) FOMO (Fear of Missing Out). Activities of US informants who mostly focus on doing final. Then when he saw his friends who had gone a step further. The US informant also tried to compare his achievements with those of his friends on Instagram; (2) Feeling jealous of the lives of others. US informants feel their life is unfair when comparing their lives with others. One of them when doing the final project, many of his friends made Instagram Stories about the fun, smooth running of their final project. The US informant feels that seeing a story creates negative energy so that he doesn't need to see the story; (3) Instagram is the biggest source if you want to shop for consumptive alias; (4) Wasting time because it is very addictive and makes it unfocused; (5) Tired of the new habit of Instagram users who always upload stories almost every chance. US informants feel they don't really 
like the habit. Sometimes even a US Informant friend feels offended, if the US Informant does not do an Instagram Story update. Therefore, the US informant decides to leave Instagram so he has a reason that his friend is not offended.

Almost similar to the US, TL is an informant (2018) that has done Instagram fasting because according to him using Instagram is just a waste of time or wasting time, moreover at this time he is busy with his work so Instagram is just a distraction.

The feelings expressed by US (informant) was almost similar to those of RW (informant). RW revealed that Ig fasting is done to be alone and away from his friends. RW did fasting because of feeling insecure about the achievements of his classmates who had graduated and there were even some who had worked, while he was still in the process of struggling to complete his thesis. "I'm a very introverted child, it's up to people to say bastard or something but what I feel is often very sad, especially if I have seen Insta Story, really really annoyed seeing my friends I've graduated, playing here and there, there are who already gets a job while I'm still in this circle. I decided to disappear from all social media, especially Instagram, because it is really the most evil, like an event to show off like that even though I don't know if it's really the real condition or not. While FC (informant), Instagram as social media until now is a place to show off. FC (2018) has fasted Instagram for more than a month. The thing that made him do Instagram fasting was because of his own desire to be more focused with what was done. "Ig Fasting is also taught by my friends too. He was taught to be kept informed ... good results

The FC (2018) said about the revealed of the reasons in detail,

"I fasted Ig around May. At that time fasting was because I had too many people showing off. For example eating where photographed, then hang out where to be photographed. Many people show off on Ig. So I don't want to play Ig again. Well there I detox / fasting so as to ease my mind, so as not to compare my life with the lives of others. That was first showing 
off. And secondly, for example there are achievements of people. People get achievement, people take photos with Jokowi, everything is like that right. Even though life actually doesn't need everything to be exhibited. In addition, too much negative content like gossip goes to search or explore on Instagram. Like there might be friends who like to end up like a mutual connection. Well actually that's like that which is really toxic. Continue to try how to do it? Finally, I'm fasting. I uninstalled Instagram. And then detox. "

Unlike the case with NR Informants, he does Instagram fasting because when opening all of his friends' Instagram stories, there are unpleasant feelings that come to him, such as sadness and tightness in the chest. Also, NR felt that his life was useless, useless, not crowded, and uncomfortable as others. Besides that, the number of college assignments at that time was the reason he had to do Instagram fasting. From Instagram fasting, NR realized that being too upset with other people's lives was not good.

The feature that makes NR to Instagram fasting is Instagram Story. NR felt that the story was like an event to show the good side of life which made him feel bad. "Actually, until now I rarely see stories of friends especially if I still see the post. Because the story is like everything my friends have done is revealed there, so I know what my friend is happy about, just got a good job where, again where is the vacation where the average makes me jealous. Now I know the cause so I avoid things like that, it seems like I don't care about other people, but how is it, my mood is more important ( $\mathrm{Nr}, 2018)$."

Someone else is RY who an informant has fasted Instagram by deactivating Instagram accounts. The main reason he did that was because RY was having a broken heart due to a breakup. Another reason is because on Instagram Story many of RY's friends upload moments that make them mentally depressed, like the final thesis trial moment. Besides that, he also feels bored with monotonous Instagram content. RY informant also decided that his mind was not disturbed, he chose to deactivate his Instagram account. 
Almost similar to RY informants of the main reason, FO (2018) has done fasting Instagram because it gives rise to feelings of jealousy in him when he sees happiness in someone else's posting. FO revealed that according to him Instagram is an imaging event where the happiness that is shown by its users is just a fake. So in the end he decided to do Instagram fasting. "I was early on why I used to use it because I see the ex, I often post with new girls, and besides that sometimes I like to see other people how their lives are happy, but once they were too rich they realized that Instagram turns out to be an imaging event where people -people try to display their life-forms that look perfectly happy but in reality it's not all like that, and why I can say it like this because my friends like it and even myself have experienced it.

Almost similar to FO, CI (informant) said in 2018 about revealed that in addition to being bored with cyberspace, Instagram was just a mere stage for him. "Besides being so saturated, honestly, this is what I feel about what other people show on Instagram, which they post sometimes like to meet according to reality. It's not that far, my friends near me and I sometimes like to be like it.

Another case with TA (informant) who realize that they are addicted to Instagram Story and explore what is on Instagram. He always wants to spend Instagram Story in the timeline even though he does not see the contents of Instagram Story. TA informants are well aware that their daily life is spent by accessing Instagram. Then he felt uneasy when there were no more stories he could see. He is afraid of himself who feels addicted to Instagram. The TA informant is aware that he cannot control himself from Instagram. Therefore, he uninstalled the application at that time.

$\mathrm{KH}$ (informant) considers Instagram as a platform where we can see new things as long as they are used correctly. $\mathrm{KH}$ has done fasting Instagram because initially he was lazy to open Instagram because 
many of his friends had already stepped into the next phase of life. In this case, the informant compared his life with others. Specifically, he was uncomfortable because his colleagues graduated from college and got bachelor's degrees, uploaded graduation photos and so on. He then tried to interact with them by giving a comment through the comments column, but instead he asked when he would catch up. That made $\mathrm{KH}$ uncomfortable, so he decided to uninstall Instagram and deactivate the account for one month (Kh, 2018).

KH's assume (2018), "I have a lot of contents that show off, like where, what are you doing, and so on. At the time when my position was not able to be rich, it was rather uncomfortable, so fasting at that time". $\mathrm{KH}$ also admitted that actually from the beginning he rarely used Ig. $\mathrm{He}$ only occasionally uploads photos and the rest only watches mukbang and Instagram Stories from his friends.

$\mathrm{CC}$ has done fasted Instagram for one month. The main reason is because he feels he is too preoccupied with his cellphone. In addition, CC felt that the activities he carried out were not optimal, the mind was only focused on seeing what was happening on social media. So, CC thinks that there needs to be a refreshment for him to fill his spare time with other things such as pursuing his hobby. As long as the Informant CC fasts Instagram, he also fasts Twitter. CC only lasted for Twitter fasting for only two weeks.

Next, FZ revealed the reason why he decided to fast the instagram because he was lazy and to be on guard when asked questions related to his work at the time. Another reason is FZ wants to focus on finding work first, and before getting a job FZ will not start using the instagram application again on his cellphone.

Fz (2018) said that "I graduated a few months ago, I like being a bit proud and uncomfortable, sometimes if we post on Ig, whatever it is, surely someone will ask, bro, where do you work now? what are you busy and so on, now I'm lazy, I'm surprised people like to really take care of 
other people's lives, so I decided to gapake Ig, before I get a job yes at least keep working. So in the early days of fasting I deleted the photos and videos on Ig. There are also a few that I archive, right? After all, I really didn't open Ig, but didn't delete my account or deactivated it. And sometimes there are some friends who like to ask which of your Ig Zal, yes, I'll just answer if I'm on vacation or not use Ig for a period of time that hasn't been determined yet"

The experience felt by informants who do Instagram fasting can be categorized into two namely positive and negative. Positive impacts include being more productive, focusing on their daily activities, calmer, more grateful for life, not comparing life with others, increasing direct social interaction, being able to determine the type of social media that matches their personalities, using social media more wisely, can control themselves so as not to access social media as intensely as they do Instagram fasting, feeling that Instagram is not the only platform to show their existence.

The informants who do this Instagram fasting many are turning to other social media that feels suitable to their personalities and needs. Social media such as Twitter, Facebook and Youtube can be said to have clear and specific goals. Twitter is a suitable platform to be used to spread writing and thoughts. Facebook is suitable for users who like to interact with old friends and in groups. While Youtube is suitable for finding entertainment.

One of the most widely used is Twitter. Currently the use of Twitter in Indonesia is on the rise again. The informants who "migrated" from Instagram to Twitter felt that Twitter was more peaceful, more informative, had a lot of humor accounts, and the characteristics of Twitter users were more relaxed. They do not feel the symptoms of Fear of Missing Out (FOMO) when using Twitter. The average informant only uses Twitter 3 times a day and is not as intense when using Instagram. The informants felt themselves more focused on each other's real life such as lectures and work. 
When DF Informants don't access Instagram, he still accesses Facebook and Twitter. He claimed that he could never leave the two social media since he first created an account. DF informants feel Twitter always provides the latest information needed. Meanwhile, Facebook is a platform that allows him to interact with old friends and teachers during school.

In line with DF, NR also returned to playing Twitter. NR called Twitter as a means of escaping from Instagram. He chose Twitter because no one likes to show off in it. Instead he gets entertainment and exciting jokes. In addition, he also uses the Whatsapp and Line messaging application to interact with his friends.

OTN informants felt the time was more useful after fasting Instagram. He also claimed the level of "kemageran" or the level of laziness he was reduced. Besides that, the OTN informant claimed that he was no longer fixated on his cellphone. OTN (2018) said, 'To be honest, I used to be able to open the Ig every time when I held the cellphone. And it was panic in the first place if I didn't open IG, I didn't want to miss the activities of people. Yes, the main thing is Ig makes addicts, but now I have lots of time to do other things because it reduces.

US (2018) also remained active in using Twitter because according to him it was more lonely. Following are the US statements, "it's lonely in terms of interactions with colleagues and relatives that on Twitter there aren't many that are active. And what I follow is usually jokes accounts or all informative accounts. So FOMO and others don't feel right when I use Twitter. That, too, I can open Twitter 2-3 days only because it is not as addictive as Ig I think .. Besides that also because my goal is fasting Ig would not want to reduce the intensity of the use of social media and focus more on thesis and side jobs (As, 2018).

RY managed to do Instagram fasting for a month. He also felt that his life was better, plong (relieved), and could focus on doing other things 
that were more useful during Instagram fasting. "You can't deny that playing Ig can disturb you too. Besides that, it saves quota too. Although it is undeniable that RY feels he missed a few things on Instagram. Like when a friend of his game talks about something and only RY himself doesn't know about it because he doesn't have an Instagram account.

As long as RY informants do Instagram fasting, he only uses social media Twitter. Twitter is considered more informative because there are many news accounts and important news. Unlike Instagram, which only contains people who take care of their feed (main page view) to make it look good.

The negative impact of doing Instagram fasting felt by the informants is feeling awkward when starting and lagging behind things that are viral on Instagram.

According to TL (2018), Instagram fasting makes it less up to date on news that is being viral. TL said, "I am not up to date, you know, the majority of those who are viral are on Instagram, sometimes I feel like I miss the most info when my friends are discussing it and I usually find out via Google".

A similar experience was reinforced by the opinion of Ci (2018), who revealed that by reducing Instagram usage, he was not up to date on information that was being viral on Instagram. "So I feel like I have missed info, for example news that is more trendy or up in the Ig, then for example the old tea doesn't open Ig suddenly when it's open eh my friend already graduated, married, even crushed or even knew his fiance.

As experienced by TA, in first time he felt empty and longed to access Instagram. TA felt left behind because many of his friends contacted him via Instagram's Direct Message rather than Line. In addition, TA feels he is lagging behind a lot of things that are only viral on Instagram. It's like rocking Lucinta Luna. But gradually, TA felt a positive impact. He felt more productive and his life became calmer when uninstalling 
the Instagram application. The reaction of TA's Informant friends was when he found himself fasting from ordinary Instagram. They assume it is normal and natural to take a break from Instagram.

The same is true of the Informant $\mathrm{KH}$. He felt lonely at first because he was accustomed to opening explore on Instagram. Gradually, approximately 1 week $\mathrm{KH}$ informants felt comfortable, he could complete his assignments as a student well without Instagram distraction. $\mathrm{KH}$ informants can also return to their old hobbies of reading novels and completing several novels. One week for $\mathrm{KH}$ Informants is enough to make him no longer think of opening Instagram. Until one day he had to reaccess Instagram because he had to contact someone through Instagram's Direct Message which can only be contacted through the social media.

Some social media that $\mathrm{KH}$ Informants use when fasting on Instagram include Youtube, Buzzfeed, and Twitter. However, he is also very rarely in accessing social media. Youtube for him is a lot of interesting shows and there are no uploads from his friends. Buzzfeed He uses to read gossip from Hollywood artists. While Twitter, he uses because a lot of new information he got from Re-Tweet his friends. In addition, $\mathrm{KH}$ also uses the messaging application to connect with others.

Some $\mathrm{KH}$ friends also knew that he was not using Ig when his friends tried to mark $\mathrm{KH}$ in a photo upload. The reaction of $\mathrm{KH}$ 's friends when they found out $\mathrm{KH}$ uninstalled was they smiled while accepting $\mathrm{KH}$ 's decision because they thought that $\mathrm{KH}$ would use Ig again not long after uninstalling.

DF informants consider Instagram is a platform as a means of entertainment. But for him Instagram is not always entertaining, because Youtube is more entertaining. DF informant once uninstalled the Instagram application from his cellphone because he experienced a breakup so he wanted to calm down by removing the application. Until in the end he got used to without Instagram. However, he also feels left behind by what other 
people are doing. For example when he chatted with a friend whose subject was someone else's Instagram, there he felt left behind.

Similar to a number of other informants, the FO confessed that the beginning of the time he decided not to use Instagram at all, arose in him a feeling of curiosity, a feeling of loneliness, and felt there was no entertainment he could get. He revealed that to get rid of his loneliness, he switched to opening Facebook and Youtube.

\section{After Doing Instagram Fasting}

After doing Instagram fasting, things are also different. There are people who re-access Instagram, there are also those who leave Instagram forever. The informants on average began to get used to the intensity of the use of Instagram which was reduced quite dramatically, even can be said to be low. In addition, informants also learn to access useful content such as news and infographics. The informants also followed accounts that had a positive impact on their lives such as humor accounts. There are also those that turn off notifications to reduce distraction. There are also those who even though the application still exists in the cellphone but the account conditions are logged out. Finally, there are informants who feel that they do not match the experience provided by Instagram. After he fasts, he is more determined to delete his account forever, uninstall the application, and switch to using other social media that is better suited to his character and healthier for him.

RY (2018) claimed that before he fasted Instagram always used the application until the countless hours he used to access Instagram. Almost every time RY uses her cellphone, she always opens and plays Instagram. "Everytime I open my cellphone, I open it. I don't know how many hours it takes, don't just watch the leading stories and don't scroll the timeline."

After fasting Instagram, by itself there was a change in RY Informants about the length of time using Instagram. What RY Informants 
do when using Instagram only sees the front story and scrolls the timeline but not to the very bottom timeline. In other words, even though the intensity of the RY Informant in opening the Instagram application is still the same, that is, up to five times a day, but he has been using Instagram less. He only saw the leading story for about 15 minutes and the timeline scroll was no more than 15 minutes.

The FC informant after Instagram fasting clearly stated, "What is certain is to do everything that is more informative compared to things that are toxic"

There are also informants who decide not to use Instagram anymore or deactivate an account because they are not interested in Instagram. KZF informant stated that he was no longer interested in Instagram at this time with all the features that had begun to develop. When KZF was still using Instagram, all he did was check the Instagram Story of his friends, scroll the timeline to the bottom, when he was bored and just closed the Instagram application. He then felt he was not interested in spreading his personal life for public consumption in the social media universe.

Likewise with the DS Informant. Since the beginning of Instagram, DS Informants felt they did not fit into the application. In fact, several times he had deleted the account. DS then decides to switch to other social media that is more suited to his personal character.

The DS informant created an Instagram account with a real name in 2015 because it followed the trend. But unfortunately, the account is not maintained so he uninstalled again. The DS informant felt the need when he had to contact several sources for his research which was easiest to do if via Instagram. After that he re-uninstalled the application. Because he felt incompatible with Instagram and removed the application several times, finally when he wanted to return to Instagram now with all the features that had been developed, he felt strange. Strange in the sense that he is confused with Instagram features. With his current condition who 
has worked in the field of communication and mastering social media is an obligation (digital savvy), he feels that mastering Instagram and understanding what is in it is also necessary. But because basically he doesn't fit Instagram, he feels awkward when he uses social media.

DS informants still remain loyal to Facebook and Twitter. Both of these social media benefits were felt by the Informant DS because they gave the information as he wanted. Facebook gives him the best experience when it comes to groups. In Facebook there is a group facility that allows him to follow the information he wants and thinks is fun. As an example is the Commuter Line Group, which uploads always fast in updating information and contains humorous content that he thinks is fun. Besides that there are also scholarship groups which he thinks are useful to be followed. While Twitter, according to him is more exciting than before. Lots of threads, information, and useful content.

Similar to a number of other informants, FO Informants revealed that since he fasted Instagram, his life felt to be calmer, not easily agitated, and even more able to respect the privacy of his life. Despite fasting, Instagram FO claimed to continue to use social media and was not afraid to get addicted as before. However, FO does not have a single collection of photos uploaded on his personal Istagram account. FO also said that he currently rarely uploads Instagram stories on his account

TL informant revealed that with Instagram fasting, he was more able to enjoy his time in the real world and rarely uploaded his personal photos. Similar opinion was strengthened by CI's statement which revealed that with fasting Ig, he became more enjoying life in the real world.

The RW informant also strengthened the statement of the TL and CI informants that after fasting Ig, he became more calm, safe, peaceful and enjoy living his life even though he was still struggling with his final assignment. 
Furthermore, FZ informants revealed that after fasting, Ig had become more selective in following certain Instagram accounts. He revealed that he often followed jokes accounts and used twitters afterwards. FZ thinks that twitters are healthier than Igs, twitters are far more informative and have quality content.

Table 1 Matrix Phase Before, During, and After Doing Instagram Fasting

\begin{tabular}{|c|c|}
\hline PHASE & FEATURES \\
\hline $\begin{array}{c}\text { BEFORE DOING } \\
\text { INSTAGRAM FASTING }\end{array}$ & $\begin{array}{l}\text { - Addicted to Instagram } \\
\text { - Fear of Missing Out (FOMO) } \\
\text { - Fear of being labeled negatively by friend } \\
\text { - Comparing life with others } \\
\text { - Restless when not accessing Instagram } \\
\text { - Envy / Jealous with others } \\
\text { - Not Productive }\end{array}$ \\
\hline 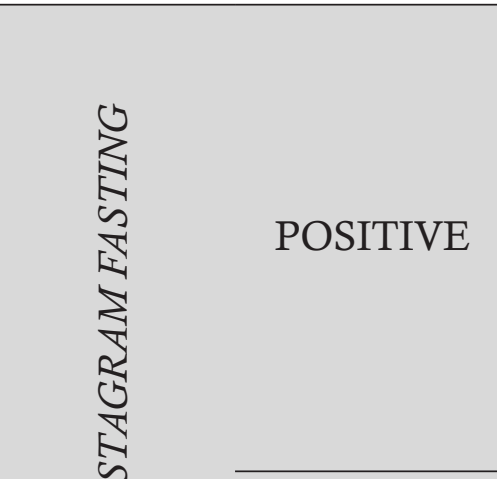 & $\begin{array}{l}\text { - Productivity increases } \\
\text { - More respect for face-to-face socialization } \\
\text { - Distraction decreases } \\
\text { - Life is calmer } \\
\text { - More positive thinking } \\
\text { - More respect for life } \\
\text { - Increase self-confidence } \\
\text { - Respect privacy } \\
\text { - Pursue a hobby } \\
\text { - More creative }\end{array}$ \\
\hline NEGATIVE & $\begin{array}{l}\text { - Awkward when beginning fasting } \\
\text { - Behind something viral on Instagram } \\
\text { - Feel lonely }\end{array}$ \\
\hline $\begin{array}{c}\text { AFTER DOING } \\
\text { INSTAGRAM FASTING }\end{array}$ & $\begin{array}{l}\text { - Instagram's intensity has decreased } \\
\text { - Only access useful content } \\
\text { - Delete an Instagram account } \\
\text { - Switch to other social media } \\
\text { - Follow accounts that have a positive impact } \\
\text { - Disabling notifications, log out account } \\
\text { - Not dependence }\end{array}$ \\
\hline
\end{tabular}

Source: Research Result, 2018 
A psychologist from Padjadjaran University, Julian Amriwijaya (in Kurniasih, 2017) stated, "It is hard to change a pattern of repeated behavior that brings certain pleasure, it needs another thing to substitute the pleasure and strong will with oneself. (It's hard to change the recurring behavior patterns that give rise to certain pleasures, something else needs to replace the strong pleasures and wishes with yourself). "When elaborated in this study, the informants realized that something was wrong with them when accessing Instagram. They also want to change, reduce the "poison" from Instagram so that their lives are happier with positive thoughts. The informants set goals accompanied by a strong commitment from themselves to achieve goals so that their lives are happier with positive thinking. The informants substitute the fun they get on Instagram with other social media that is more positive and does not give another "poison" to the lives of the informants.

Informants who do Instagram fasting are actually changing behavior patterns for the better. The informants replaced the fun they got from Instagram by switching to other social media that they felt were more positive, such as Twitter, Facebook and Youtube. The informants also have a strong will of themselves by finding out what is wrong with themselves when accessing Instagram. Although self diagnosis was forbidden in psychology, the informants luckily managed to find the cause. They also look for references about what they are going through and exchange ideas with friends who have done Instagram fasting.

In the context of interpersonal relations and social psychology, the substitution made by the informants is in accordance with the Social Exchange Theory expressed by Harold Kelley, George Homans, Richard Emerson, and Peter Blau. Social exchange theory is a theory that elaborates on how interpersonal relationships seem to be trade transactions that allow each transaction to be influenced by rewards, costs, and profits. In this case, a person tends to repeat the same behavior or change the behavior when the value or results are obtained proportionately or even more than the investment itself. (Cook, 2003; R. Cropanzano and M.S. Mitchell, 2005) 


\section{Conclusion}

Instagram is a visual-based platform that has rapidly evolved its functions and benefits, it is very fun, but at the same time scary. Instagram is a platform that is suitable for spreading anything that smells of visuals in order to achieve visual pleasing. In addition to business, personal branding, not infrequently also be misused for public fraud. The informants agreed that Instagram was inspired too much by the features of other applications. In other words, Instagram seems to be a "cannibal" for other social media.

Instagram fasting is done to reduce the intensity of the use of Instagram social media. This is done by removing applications from the mobile; deactivate an account; do not access the Instagram version of the website on a computer; restrict yourself to access Instagram even if you don't delete the app; turn off Instagram notifications completely; and tell colleagues that they are not using Instagram.

The main reason for doing Instagram fasting is because of the inconvenience of the Instagram experience. The informants agreed that Instagram is currently a poison in life. They seemed to be chased by something that was so obsessed that they were afraid to miss something or Fear of Missing Out (FOMO). The use of Instagram Story is currently only used as a place to show off "the perfect life".

The things that are felt when doing Instagram fasting include they feel more productive, more focused on their daily activities, more positive thinking, do not compare life with others, and can determine the type of social media that fits their personality. The informants who do this Instagram fasting many are turning to other social media such as Twitter, Facebook and Youtube.

After fasting, some informants returned to access Instagram and some left Instagram forever. When returning to Instagram with a lower intensity, accessing useful things, and following positive accounts. There is 
also an informant who permanently deletes the account and uninstalles the application because he has found no compatibility with Instagram anymore.

The informants suggested that Instagram improve the user experience so that they can adjust their privacy according to their wishes. Instagram is expected to give flexibility to Instagram users to manage uploads and filter negative comments. Users should be given the freedom to upload something on the main Instagram page or home based on likes, prefered friends, or based on time. So, users can determine their own experience they want to feel when using Instagram on their main page. Not exactly regulated by Instagram.

The informants also agreed that before Instagram added new features, it would be better if the survey producers were suitable or not. In addition, Instagram producers should provide clear guidelines and limits on features. For example, the Instagram Story feature seems to replace Instagram's main function, which is uploading photos. Now many users pay more attention to Instagram Story. Research informants are sometimes disturbed by the polling feature because the questions asked are not important and tend to be "what people say". There were also informants who were disturbed by the video call and voice message features that were deemed incompatible with Instagram.

\section{Bibliography}

Cook, K.S. and E. Rice. 2003. Chapter 3: Social Exchange Theory. In J. Delamater (Ed.), Handbook of Social Psychology. New York: Kluwer Academic/Plenum Publishers.

Cropanzano, R. and M. S. Mitchell. 2005. "Social Exchange Theory: An Interdisciplinary Review". Journal of Management, Vol. 31, No. 6, pp. 874-900.

Kurniasih, Nuning. 2017. "Internet Addiction, Lifestyle or Mental Disorder? A Phenomerencenological Study on Social Media 
Addiction in Indonesia, The International Conference on Design and Technology, KnE Social Sciences", 135-144. DOI 10.18502/ kss.v214.879

McCloskey, W., Iwanicki, S., Lauterbach, D., Giammittorio, D.M., \& Maxwell, K. 2015. "Are Facebook "Friends" Helpful? Development of a Facebook-based measure of social support and examination of relationship among depression, quality of life, and social support. Cyberpsychology", Behavior, and Social Networking, Vol. 18, No.9, pp. 499-505.

Musfah, Jejen. 2004. Risalah Puasa, Menjadikan Bulan Ramadhan Sebagai Bulan Penuh Pahala. Yogyakarta: Hijrah

Primack, B.A., Shensa, A., Escobar-Viera., C.G., Barrett, E.L., Sidani, J.E., Colditz, J.B. \& James, A.E., 2017. "Use of Multiple Social Media Platforms and Symptoms of Depression and Anxiety: A Nationally-Representative Study among US Young Adults". Computers in Human Behavior, Vol. 69. No. 1. pp. 1-9.

Radovic, A., Gmelin, T., Stein, B.D., \& Miller, E. 2017. "Depressed adolescents' positive and negative use of social media". Journal of Adolescence, Vol. 55, No. 1, pp. 5-15.

Shensa, A., Sidani, J.E., Dew, M.A., Escobar-Viera, C.G., \& Primack, B.A. 2018. "Social Media Use and Depression and Anxiety Symptoms: A Cluster Analysis". American Journal of Health Behavior, Vol. 42, No. 2, pp. 116-128.

Smith, J. A., P. Flowers, and M. Larkin.(2009. Interpretative Phenomenological Analysis: Theory, Method, and Research. Los Angeles, London, New Delhi, Singapore, Washington: Sage.

Zahavi, D. 2003. Husserl's Phenomenology. Standford California: Standford University Press. 


\section{Internet}

Haux, Paulina \& Elisabet Lund. (2018). "The Socia Media Paradox. How The Social Media and Influencers Affect Consumers' Perception of Quality of Life. Critical Studies of Marketing and Consumption. Diakses dari

https: / $/$ www.google.com $/ 1$ ? sa $=$ t\&rct $=\mathrm{j} \& \mathrm{q}=\&$ esrc $=\mathrm{s} \&$ source $=\mathrm{w}$ eb\&cd $=1 \&$ cad $=$ rja\&uact $=8 \& v e d=2$ ahUKEwjA66zdlbDfAhUY WX0KHSu7DGEQFjAAegQIChAC\&url=http $\% 3 \mathrm{~A} \% 2 \mathrm{~F} \% 2 \mathrm{Fl}$ up.lub.lu.se\%2Fstudent-papers\%2Frecord\%2F8945952\%2Ffile\% 2F8945957.pdf\&usg=AOvVaw0i1T--SzzVwUmnK7cOlaC4

Wahyuni, Nopitri. (2018, Agustus 8). Adiksi Media Sosial dan Kecemasan Eksistensial. Diakses dari https://medium.com/@nopitriw/adiksimedia-sosial-dan-kecemasan-eksistensial-5dc892652537

Youtube. (2017, Juni 22). Is Social Media Hurting Your Mental Health? | Bailey Parnell | TEDxRyersonU. Diakses dari https://youtu.be/ Czg_9C7gw0o

Zaenudin, Ahmad. (2018, Agustus 7). Keinginan Mendapatkan "Likes" dan Kecanduan Pada Teknologi. Diakses dari https://tirto.id/keinginanmendapatkan-likes-dan-kecanduan-pada-teknologi-cQxd

\section{Interview Source}

Ajeng. (2018, 10 Desember). Personal Interview.

Aji, Dimas Bayu. (2018, 10 Desember). Personal Interview. Augustine, Thalia. (2018, 10 Desember). Personal Interview.

Clarissa, Raden Roro. (2018, 10 Desember). Personal Interview.

Claudia, Fabella. (2018, 10 Desember). Personal Interview.

Claudya, Chindy. (2018, 10 Desember). Personal Interview.

Fauzia, Dila. (2018, 10 Desember). Personal Interview.

Firdausi, Karina Zalfa. (2018, 10 Desember). Personal Interview.

Herdian, Krisna. (2018, 10 Desember). Personal Interview.

Nurrizky. (2018, 10 Desember). Personal Interview. 
INJECT (Interdisciplinary Journal of Communication), Vol.4, No.2, Des. 2019: p. 191-218

Otniel. (2018, 17 Desember). Personal Interview.

Rahma, Alifah. (2018, 9 Desember). Personal Interview.

Rhendy. (2018, 16 Desember). Personal Interview.

Sharaswati, Dwi. (2018, 10 Desember). Personal Interview.

Shinta, Angela. (2018, 10 Desember). Personal Interview. 